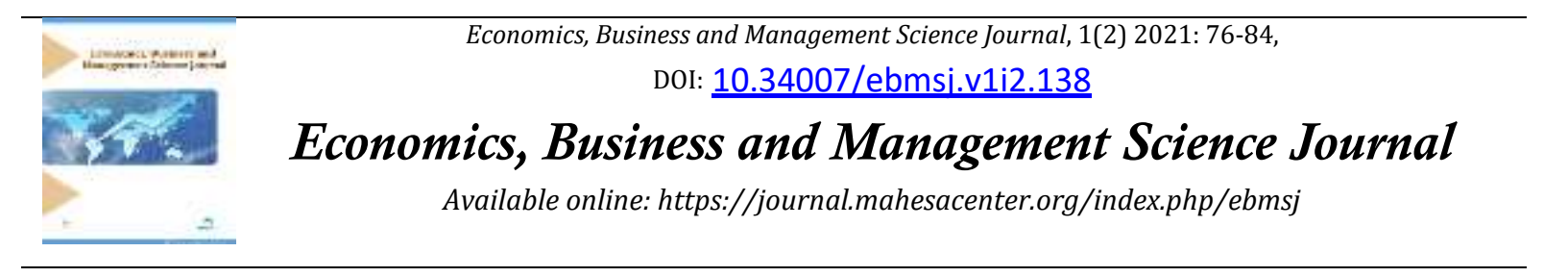

\title{
Pengaruh Ukuran Perusahaan dan Umur Perusahaan Terhadap Tax Avoidance pada Sektor Pertambangan di BEI
}

\author{
The Effect of Company Size and Company Age on Tax \\ Avoidance in the Mining Sector on the IDX \\ Firmansyah \\ STMIK Dharmapala Riau, Indonesia
}

\begin{abstract}
Abstrak
Tujuan penelitian ini adalah untuk mengetahui pengaruh ukuran perusahaan terhadap tax avoidance pada perusahaan pertambangan di BEI, untuk mengetahui pengaruh umur perusahaan terhadap tax avoidance pada perusahaan pertambangan di BEI, dan untuk mengetahui pengaruh ukuran perusahaan dan umur perusahaan terhadap tax avoidance pada perusahaan pertambangan di BEI. Hasil penelitian ini adalah ukuran perusahaan, dan umur perusahaan berpengaruh terhadap tax avoidance baik secara parsial maupun simultan

Kata Kunci: Ukuran Perusahaan; Umur Perusahaan; Tax Avoidance

Abstract

The purpose of this study was to determine the effect of company size on tax avoidance in mining companies on the IDX, to determine the effect of company age on tax avoidance in mining companies on the IDX, and to determine the effect of company size and company age on tax avoidance in mining companies on the IDX. The results of this study are the size of the company, and the age of the company affect tax avoidance either partially or simultaneously

Keywords: Company Size; Company Age; Tax Avoidance

How to Cite: Firmansyah. (2021). Pengaruh Ukuran Perusahaan dan Umur Perusahaan Terhadap Tax Avoidance pada Sektor Pertambangan di BEI. Economics, Business and Management Science Journal, 1(2) 2021: 76-84,
\end{abstract}

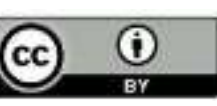




\section{PENDAHULUAN}

Dalam Undang-Undang KUP tahun 2013 Pasal 1 ayat 1 Pajak merupakan kontribusi wajib kepada Negara yang terutang oleh orang pribadi atau badan yang bersifat memaksa berdasarkan undang-undang, dengan tidak mendapatkan imbalan secara langsung dan digunakan untuk keperluan Negara. Pajak menjadi sumber penerimaan Negara terbesar di Indonesia, sehingga pajak memiliki peran penting dalam kehidupan bernegara. Pajak digunakan untuk membangun infrastruktur, biaya kesehatan, biaya pendidikan, membangun fasilitas publik serta untuk membayar para pegawai negara. Semakin banyak pajak yang diterima pemerintah maka akan semakin banyak fasilitas dan infrastruktur yang akan dibangun. Peranan pajak yang penting bagi suatu Negara tidak menjadikan para wajib pajak untuk tetap membayar kewajibannya.Terbukti dengan penerimaan pajak yang diterima pemerintah Indonesia beberapa tahun ini mengalami penurunan. (Sinaga dkk, 2020; Simarmata dkk, 2020).

Badan Pemeriksa Keuangan (BPK) menyebutkan realisasi penerimaan pajak berbeda dengan target penerimaan dipicu oleh tiga faktor utama yaitu kebijakan pajak, institusi pajak dan wajib pajak. Pohan (2013) menyatakan bahwa salah satu yang menjadi faktor dalam penurunan penerimaan pajak dari target yang telah ditentukan adalah kesadaran wajib pajak itu sendiri. Semenjak reformasi perpajakan, sistem perpajakan berubah dari office assessment menjadi self assessment (PPh dan PPn). Berdasarkan sistem ini, wajib pajak memiliki hak dan kewajiban, baik menghitung, membayar, dan melaporkan sendiri jumlah kewajiban perpajakannya. Hal ini akan terlaksana dengan baik apabila wajib pajak mematuhi peraturan - peraturan sesuai undangundang. (Lubis dkk, 2020; Astika dkk, 2020).

Salah satu upaya pemerintah untuk meningkatkan penerimaan pajak adalah dengan melakukan perbaikan dan penyempurnaan peraturan pajak di Indonesia. Tujuan perubahan peraturan perpajakan yang dilakukan pemerintah adalah untuk memperbaiki sistem perpajakan dan meningkatkan jumlah penerimaan Negara di sektor pajak.

Perbaikan peraturan yang telah dilakukan pemerintah diharapkan untuk para wajib pajak baik pribadi maupun badan dapat meningkatkan kesadarannya berpartisipasi dalam proses pembangunan melalui pembayaran pajak dengan sukarela menghitung dan membayar sendiri pajaknya. (Jonathan \& Effendi, 2020; Rahmadhani, 2019).

Beberapa tahun terakhir otoritas pajak telah berusaha dengan semaksimal mungkin tidak hanya dengan menegakkan batas yang jelas antara penghindaran pajak dan penggelapan pajak dalam upaya perencanaan pajak, tetapi juga untuk mencegah wajib pajak masuk kedalam celah ambiguitas yang ditimbulkan oleh peraturan pajak. Dengan dilakukannya audit intensif, tekanan prosedural publisitas yang mempengaruhi reputasi diharapkan mampu untuk mencegah para wajib pajak menggunakan struktur penilaian terhadap status hukum yang ambigu.Perbedaan kepentingan mengenai pajak yang terjadi antara pemerintah dengan wajib pajak menyebabkan pajak yang seharusnya diterima oleh pemerintah menjadi tidak sesuai dengan yang diharapkan. (Nasution, 2016; Paningrum \& Usman, 2016).

Berdasarkan sudut pandang dari pemerintah, wajib pajak diharapkan melaksanakan kewajiban perpajakan semaksimal mungkin dengan begitu penerimaan Negara dari sektor pajak akan bertambah dan sebaliknya apabila pajak yang dibayarkan oleh wajib pajak lebih kecil dari yang seharusnya mereka bayar, maka pendapatan Negara dari sektor pajak akan berkurang. (Prayudi \& Ilhammi, 2015; Syahrial \& Robica, 2014).

Fenomena kasus tax avoidance terjadi pada PT Coca Cola Indonesia. Dalam kasus ini PT CocaCola Indonesia diduga melakukan penghindaran pajak yang menimbulkan kekurangan pembayaran pajak senilai Rp 49,24 miliar. Berdasarkan hasil penelusuran yang dilakukan Direktorat Jenderal Pajak, Kementrian Keuangan menemukan terdapat pembengkakkan biaya yang cukup besar pada tahun 2002, 2003, 2004, dan 2006.Beban biaya yang besar menyebabkan penghasilan kena pajak berkurang, sehingga beban kena pajak PT.CCI mengecil. Beban biaya tersebut merupakan hasil dari pembiayaan iklan minuman merek coca cola dari rentan waktu tahun 2002-2006 dengan total sebesar Rp 566,84miliar sehingga mengakibatkan penurunan penghasilan kena pajak. Direktorat Jenderal Pajak total penghasilan kena pajak CCI pada periode itu adalah Rp 603,48 miliar. Sedangkan berdasarkan perhitungan dari CCI penghasilan kena pajak mereka berjumlah Rp 492,59 miliar. Berdasarkan selisih tersebut DirektoratJenderal Pajak 
menghitung kekurangan pajak penghasilan (PPh) PT CCI adalah sebesar 49,24 miliar. Beban biaya yang sangat besar membuat Direktorat Jenderal Pajak curiga dan mengarahkan PT CCI melakukan praktik tax avoidance (ekonomi.kompas.com). Penelitian ini dilakukan pada perusahaan pertambangann, bahwa sanya Indonesia memiliki banyak sumber daya alam yang dapat dikelola secara maksimal, dengan banyaknya sumber daya alam tersebut sudah barang tentu semakin banyak perusahaan asing maupun lokal untuk beroperasi di Indonesia dengan beroperasinya di Indonesia perusahaan seminimal mungkin untuk menghindarkan penghindaran pajak walaupun pajak menjadi pendapatan utama dari pemerintah, berikut ini pergerakan penghindaran pajak perusahaan pertambangan :

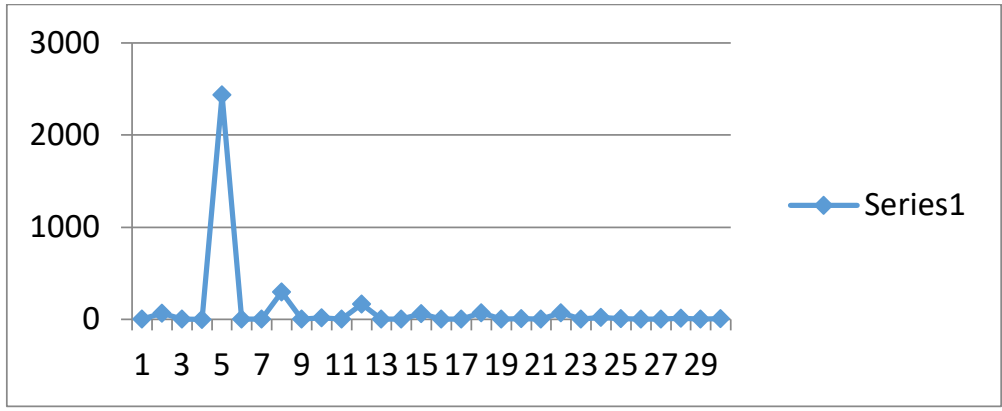

Gambar 1

Grafik Tax Avoidance Perusahaan Pertambangan

Berdasarkan pada Gambar 1 dapat diketahui bahwa perkembangan tax avoidance khususnya perusahaan pertambangan beberapa tahun terakhir mengalami ketidakstabilan bahkan ada yang mengalami kenaikan juga hal tersebut menunjukkan bahwa semakin besar juga perusahaan untuk melakukan tax avoidance dalam setiap transaksi yang mereka lakukan. Penelitian ini merupakan penelitian replikasi yang telah dilakukan oleh Rusydi (2013) bahwa ukuran perusahaan tidak berpengaruh terhadap tax avoidance di Indonesia, sedangkan Handayani (2018) dengan hasil penelitian bahwa ukuran perusahaan berpengaruh terhadap tax avoidance.

Perumusan masalah pada penelitian ini apakah ukuran perusahaan berpengaruh terhadap tax avoidance pada perusahaan pertambangan di BEI ?, apakah umur perusahaan berpengaruh terhadap tax avoidance pada perusahaan pertambangan di BEI ?, dan apakah ukuran perusahaan dan umur perusahaan berpengaruh terhadap tax avoidance pada perusahaan pertambangan di BEI ?. Tujuan penelitian ini adalah untuk mengetahui pengaruh ukuran perusahaan terhadap tax avoidance pada perusahaan pertambangan di BEI, untuk mengetahui pengaruh umur perusahaan terhadap tax avoidance pada perusahaan pertambangan di BEI, dan untuk mengetahui pengaruh ukuran perusahaan dan umur perusahaan terhadap tax avoidance pada perusahaan pertambangan di BEI.

\section{METODE PENELITIAN}

Penelitian ini dilaksanakan pada perusahaan pertambangan yang terdaftar di BEI. Sedangkan populasi penelitian ini adalah seluruh Perusahaan Pertambangan yang terdafar atau listing di BEI pada periode penelitian 2018 sampai dengan periode 2020 yang tidak mengalami delisting pada periode penelitian, yang berjumlah 37 emiten atau perusahaan. Sampel merupakan bagian dari populasi, hal ini Menurut Menurut Soewadji (2012), bahwa sampel adalah contoh, monster, representan atau wakil dari satu populasi yang an cukup besar jumlahnya yaitu sifatnya dari keseluruhannya, dalam penntukan teknik atau penarikan sampel yang dipergunakan oleh peneliti yaitu perusahaan pertambangan yang selama periode penelitianya melakukan publikasi laporan keuangan nya di website Bursa Efek Indonesia, sehingga yang didapatkan sampel penelitian ini sebesar 10 perusahaan atau emiten. Sehingga perhitungan obervasi data penelitian menjadi 3 tahun data dikalikan dengan 10 perusahaan sehingga observasi pengamatan data menjadi 30 pengamatan data. 
Jenis dan sumber data pada penelitian ini, data sekunder. Data sekunder merupakan data yang bersifat publikasi antara lain laporan keuangan perusahaan, jurnal-jurnal penelitian, dan yang sesuai dengan penelitian ini. Teknik pengumpulan data yang digunkan studi dokumentansi. Studi dokumentansi merupakan teknik pengumpulan data yang berasal dari dokumen-dokumen yang ada, peneliti pada penelitian ini menggunakan jurnal penelitian dan bahan yang terkait pada penelitian yang peneliti lakukan.

Analisis data penelitian ini dengan menggunakan analisis regresi linier berganda, dengan dasar atau prsyarat sebelum dilakukannya regresi berganda, harus melalui uji asumsi klasik penelitian yang terdiri dari uji normalitas, uji heterokedastitas, uji multikolinieritas dan uji autokorelasi.

\section{HASIL DAN PEMBAHASAN}

Dalam menjawab suatu rumusan masalah dengan didasarkan pada penggunaan analisis data, maka peneliti menggunakan analisis data regresi berganda, akan tetapi dalam hal pelaksanaan analisis data regresi berganda, maka harus dipenuhinya uji asumsi klasik data, berikut ini hasil dari uji asumsi klasik penelitian :

Uji Normalitas

Uji normalitas pada penelitian ini peneliti menggunakan Kolmogrov-Smirnov (K-S), dan scatterplot, berikut ini hasil dari uji normalitas pada penelitian ini :

Tabel 2 Kolmogrov-Smirnov

\begin{tabular}{ll}
\hline & $\begin{array}{l}\text { Unstandardize } \\
\text { d Residual }\end{array}$ \\
\hline $\mathrm{N}$ & 30 \\
Kolmogorov-Smirnov Z & 2.236 \\
Asymp. Sig. (2-tailed) & .000 \\
a. Test distribution is Normal. & \\
\hline
\end{tabular}

\section{Sumber : Data Diolah}

Berdasarkan pada Tabel 2, dari hasil K-S dapat diketahui bahwa nilai signifikansi sebesar 0,00 atau dibawah $5 \%$ hal ini dapat dipastikan data tidak terdistribusi normal, dan berikut ini juga hasil normalitas dengan menggunakan scatterplot atau grafik 
Firmansyah, Pengaruh Ukuran Perusahaan dan Umur Perusahaan Terhadap Tax Avoidance pada Sektor Pertambangan di BEI

\section{Histogram}

Dependent Variable: Tax Avoidance

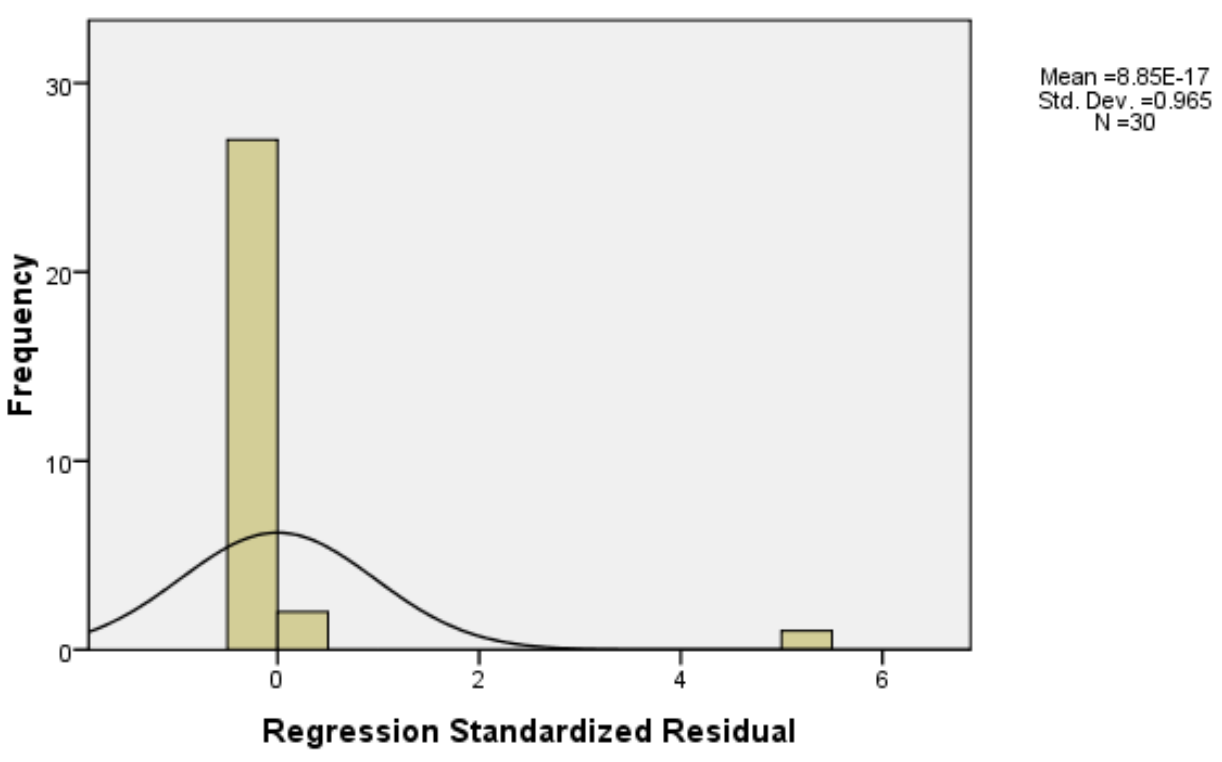

Gambar 1. Grafik Uji Normalitas Sumber : Data Diolah

Berdasarkan pada Gambar 1, dapat diketahui grafik tersebut terlihat mengalami kecondongan ke arah kiri dan bentuk hal tersebut grafik dikatakan tidak normal, maka dapat dinyatakan data tidak terdistribusi normal.

Dari hasil data tersebut data tidak terdistribusi normal, maka peneliti melakukan pengobatan data dengan cara melaksanakan SQRT, berikut ini hasil setelah dilakukan pengobatan data :

Tabel 3. Kolmogrov-Smirnov Setelah SQRT

\begin{tabular}{ll}
\hline & $\begin{array}{l}\text { Unstandardize } \\
\text { d Residual }\end{array}$ \\
\hline $\mathrm{N}$ & 23 \\
Kolmogorov-Smirnov Z & 1.115 \\
Asymp. Sig. (2-tailed) & .166 \\
a. Test distribution is Normal. & \\
\hline
\end{tabular}

\section{Sumber : Data Diolah}

Berdasarkan pada Tabel 3, dari hasil K-S dapat diketahui bahwa nilai signifikansi sebesar 0,166 atau diatas $5 \%$ hal ini dapat dipastikan data terdistribusi normal, dan berikut ini juga hasil normalitas dengan menggunakan scatterplot atau grafik : 


\section{Histogram}

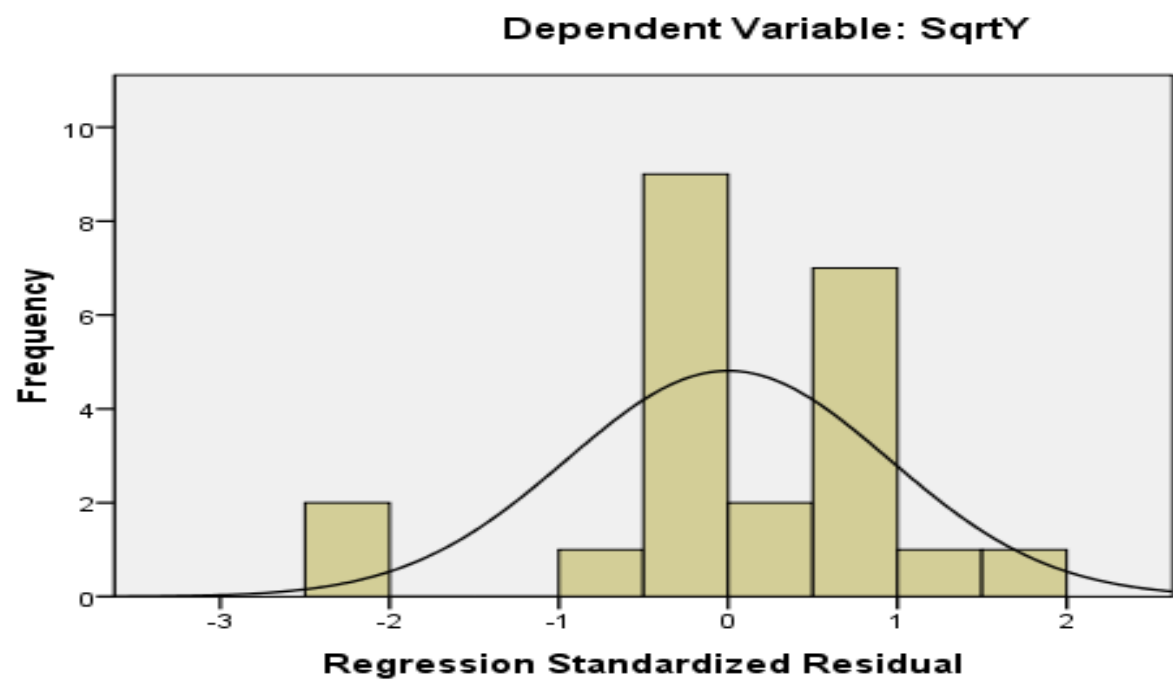

Mean $=-2.12 \mathrm{E}-15$

d. $N_{N=23}=0.953$

Gambar 2. Grafik Uji Normalitas Setelah SQRT

Sumber : Data Diolah

Berdasarkan pada Gambar 2, dapat diketahui grafik tersebut tidak terlihat mengalami kecondongan dan dapat dinyatakan data terdistribusi normal.

Uji Heterokedastisitas

Uji heterokedasitas pada penelitian ini peneliti menggunakan uji Glejser, berikut ini hasil penelitian dengan menggunakan uji Glejser adalah sebagai berikut :

Tabel 4. Uji Glejser Setelah LN

\begin{tabular}{|c|c|c|c|c|c|c|}
\hline \multirow[b]{2}{*}{ Model } & & \multicolumn{2}{|c|}{ Unstandardized Coefficients } & $\begin{array}{l}\text { Standardized } \\
\text { Coefficients }\end{array}$ & \multirow[b]{2}{*}{$\mathrm{t}$} & \multirow[b]{2}{*}{ Sig. } \\
\hline & & $\mathrm{B}$ & Std. Error & Beta & & \\
\hline \multirow[t]{3}{*}{1} & (Constant) & .720 & .185 & & 3.898 & .001 \\
\hline & LnSQRTX1 & -.093 & .043 & -.414 & -2.184 & .441 \\
\hline & $\mathrm{LnSQRTX}_{2}$ & -.382 & .112 & -.646 & -3.406 & .413 \\
\hline
\end{tabular}

a. Dependent Variable: AbsLn

Sumber : Data Diolah

Berdasarkan pada Tabel 4, dapat diketahui bahwa nilai signifikansi diatas 0,05 atau diatas $5 \%$ maka dapat dinyatakan terbebas dari gejala heterokedastitas

Uji Multikolinieritas

Uji multikolinieritas pada penelitian ini dengan menggunakan uji tolerance dan VIF, berikut ini hasil dari multikolinieritas pada penelitian ini :

Tabel 5. Uji Multikolinieritas 
Firmansyah, Pengaruh Ukuran Perusahaan dan Umur Perusahaan Terhadap Tax Avoidance pada Sektor Pertambangan di BEI

\begin{tabular}{llll}
\hline & & \multicolumn{2}{l}{ Collinearity Statistics } \\
Model & & Tolerance & VIF \\
\hline 1 & (Constant) & \\
& SqrtX1 & .844 & 1.185 \\
& SqrtX2 & .844 & 1.185 \\
\hline
\end{tabular}

a. Dependent Variable: SqrtY

Sumber : Data Diolah

Berdasarkan pada Tabel 5, dapat diketahui bahwa nilai tolerance pada variabel ukuran perusahaan dan umur perusahaan memiliki hasil 0,844 dan nilai VIF sebesar 1.185 pada kondisi yang dinyatakan tidak terjadi multikolinieritas apabila nilai tolerance $>01$, dan $\operatorname{VIF}<10$, pada hasil penelitian ini menunjukkan bahwa nilai tersebut tidak terjadi adanya multikolinieritas.

\section{Uji Autokorelasi}

Uji autokorelasi pada penelitian ini dapat dilakukan dengan menggunakan DW (Durbin Watson), berikut ini hasil dari autokorelasi pada penelitian ini adalah :

Tabel 6. Uji Autokorelasi

\begin{tabular}{llllll}
\hline \multicolumn{5}{c}{ Adjusted } & \multicolumn{2}{c}{ R Std. Error of the } \\
Model & $R$ & R Square & Square & Estimate & Durbin-Watson \\
1 & $.483^{\mathrm{a}}$ & .233 & .157 & .48344 & 1.959 \\
\hline \multicolumn{3}{l}{ a. Predictors: (Constant), SqrtX2, SqrtX1 } \\
b. Dependent Variable: SqrtY \\
Sumber : Data Diolah
\end{tabular}

Pada Tabel 6 dengan nilai DW sebesar 2.335 dengan $\mathrm{dl}=1.3520$ dan du $=1.4894$ sehingga $4-\mathrm{du}=4-1.4894=2.5016$ maka pengambilan keputusan pada autokorelasi asumsi DW yakni $1.3520<1.959<2.5016$ maka terbebas dari autokorelasi pada penelitian ini.

Tahapan setelah dilakukannya uji asumsi klasik pada dapat dilaksanakannya uji hipotesis penelitian yaitu uji parsial dan uji simultan :

Tabel 7. Uji Parsial

\begin{tabular}{|c|c|c|c|c|c|c|}
\hline \multirow[b]{2}{*}{ Model } & & \multicolumn{2}{|c|}{ Unstandardized Coefficients } & \multirow{2}{*}{$\begin{array}{l}\text { Standardized } \\
\text { Coefficients } \\
\text { Beta }\end{array}$} & \multirow[b]{2}{*}{$\mathrm{t}$} & \multirow[b]{2}{*}{ Sig. } \\
\hline & & $\mathrm{B}$ & Std. Error & & & \\
\hline \multirow[t]{3}{*}{1} & (Constant) & 2.347 & 1.106 & & 2.121 & .047 \\
\hline & SqrtX1 & .270 & .132 & .437 & 2.052 & .053 \\
\hline & SqrtX2 & .428 & .207 & .441 & 2.068 & .052 \\
\hline
\end{tabular}

a. Dependent Variable: SqrtY

\section{Sumber : Data Diolah}

1. Ukuran perusahaan memiliki nilai t hitung sebesar 2.052 dan nilai ttabel sebesar 1.750 maka thitung $>$ ttabel sehingga secara parsial ukuran perusahaan berpengaruh terhadap tax avoidane.

2. Umur perusahaan memiliki nilai t hitung sebesar 2.068 dan nilai ttabel sebesar 1.750 maka thitung $>$ ttabel sehingga secara parsial umur perusahaan berpengaruh terhadap tax avoidane 
Economics, Business and Management Science Journal, 1(2) 2021: 76-84,

\begin{tabular}{|c|c|c|c|c|c|c|}
\hline Model & & Sum of Squares & $\mathrm{df}$ & Mean Square & $\mathrm{F}$ & Sig. \\
\hline \multirow[t]{3}{*}{1} & Regression & 1.422 & 2 & .711 & 3.042 & $.070^{\mathrm{a}}$ \\
\hline & Residual & 4.674 & 20 & .234 & & \\
\hline & Total & 6.096 & 22 & & & \\
\hline
\end{tabular}

a. Predictors: (Constant), SqrtX2, SqrtX1

b. Dependent Variable: SqrtY

Sumber : Data Diolah

Berdasakan pada Tabel uji simultan bahwa ukuran perusahaan dan umur perusahaan berpengaruh terhadap tax avoidance.

\section{Pengaruh Ukuran Perusahaan Terhadap Tax Avoidance}

Ukuran perusahaan berpengaruh terhadap tax avoidance pada perusahaan Pertambangan di BEI hal ini sejalan dengan hasil penelitian yang dilakukan oleh Dewinta dan Putu Ery Setyawan dengan hasil penelitian bahwa ukuran perusahaan berpengaruh terhadap tax avoidance.

\section{Pengaruh Umur Perusahaan Terhadap Tax Avoidance}

Umur perusahaan berpengaruh terhadap tax avoidance pada perusahaan Pertambangan di BEI hal ini sejalan dengan hasil penelitian yang dilakukan oleh Dewinta dan Putu Ery Setyawan dengan hasil penelitian bahwa umur perusahaan berpengaruh terhadap tax avoidance.

\section{SIMPULAN}

Simpulan pada penelitian ini diantaranya adalah ukuran perusahaan, dan umur perusahaan berpengaruh terhadap tax avoidance baik secara parsial maupun simultan.

\section{DAFTAR PUSTAKA}

Astika, P., Marbun, P., \& Tarigan, E. (2020). Pengaruh Kepemilikan Saham Dan Corporate Social Responsibility Terhadap Nilai Perusahaan Pada Perusahaan Manufaktur Yang Terdaftar di BEI Periode 2013-2017. Jurnal Ilmiah Manajemen dan Bisnis (JIMBI), 1(1), 161-170

Br Lubis, H., Effendi, I., \& Prayudi, A. (2020). PENGARUH TINGKAT MODAL KERJA TERHADAP HARGA SAHAM PADA PERUSAHAAN OTOMOTIF \& KOMPONEN YANG TERDAFTAR DI BEI PERIODE 2014 2018. Jurnal Ilmiah Manajemen dan Bisnis (JIMBI), 1(2)

Dewinta Ida Ayu Rosa, (2016). Pengaruh Ukuran Perusahaan, Umur Perusahaan, Profitabilitas, Leverage, Dan Pertumbuhan Penjualan Terhadap Tax Avoidance. E-Jurnal Akuntansi, Universitas Udayana Bali.

Jonathan, D., \& Effendi, I. (2020). ANALISIS PENGGELOLAAN KAS DALAM UPAYA MENJAGA TINGKAT LIKUIDITAS PERUSAHAAN BONGKAR MUAT (PBM) PT. TAO ABADI JAYA JAKARTA PERIODE TAHUN 2011-2016. Jurnal Ilmiah Manajemen dan Bisnis (JIMBI), 1(1), 41-50

Musnaini, M., \& Wijoyo, H. (2021). Impact of Variety Seeking, dan Elektronic Word of Mouth of Cosmetic Brand Switching Brand Switching di Industri Kosmetik Indonesia. Ekonam: Jurnal Ekonomi, Akuntansi \& Manajemen, 3(1), 23-32.

Nasution, I. (2016). Analisis Rasio Leverage Terhadap Profitabilitas Pada Perusahaan Otomotif Dan Komponen Yang Terdaftar Di Bursa Efek Indonesia. JURNAL AKUNTANSI DAN BISNIS: Jurnal Program Studi Akuntansi, 2(2). doi:https://doi.org/10.31289/jab.v2i2.244

Paningrum, R., \& Usman, A. (2016). IMPLEMENTASI GOOD CORPORATE GOVERNANCE (GCG) DALAM MENINGKATKAN KINERJA KEUANGAN PADA PT. PERUSAHAAN GAS NEGARA (PGN) Tbk. MEDAN. JURNAL AKUNTANSI DAN BISNIS: Jurnal Program Studi Akuntansi, 2(1). doi:https://doi.org/10.31289/jab.v2i1.1721

Prayudi, A., \& Ilhammi, N. (2015). ANALISIS RASIO UTANG ATAS MODAL DAN UKURAN PERUSAHAAN TERHADAP PENGEMBALIAN SAHAM PADA PERUSAHAAN MANUFAKTUR YANG TERDAFTAR DI BURSA EFEK INDONESIA. JURNAL AKUNTANSI DAN BISNIS : Jurnal Program Studi Akuntansi, 1(2). doi:https://doi.org/10.31289/jab.v1i2.1723

Rahmadhani, S. (2019). PENGARUH MARJIN LABA BERSIH DAN PENGEMBALIAN ATAS EKUITAS TERHADAP HARGA SAHAM PERUSAHAAN INDUSTRI BARANG KONSUMSI. JURNAL AKUNTANSI DAN BISNIS : Jurnal Program Studi Akuntansi, 5(2), 170-175. doi:https://doi.org/10.31289/jab.v5i2.2795

Rusydi M. Khoiru (2013). Pengaruh Ukuran Perusahaan Terhadap Aggresive Tax Avoidance Di Indonesia. Jurnal Akuntansi Multiparadigma, Volume 4, Nomor 2. 
Firmansyah, Pengaruh Ukuran Perusahaan dan Umur Perusahaan Terhadap Tax Avoidance pada Sektor Pertambangan di BEI

Simarmata, O., Miftahuddin, M., \& Parulian, T. (2020). PENGARUH KINERJA KEUANGAN (ROA) DAN UKURAN PERUSAHAAN (SIZE) TERHADAP NILAI PERUSAHAAN (PER) PT. INDOFOOD SUKSES MAKMUR TBK PERIODE 2010-2018. Jurnal Ilmiah Manajemen dan Bisnis (JIMBI), 1(2)

Sinaga, I., Lubis, A., \& Prayudi, A. (2020). PENGARUH INTERNET FINANCIAL REPORTING (IFR) DAN TINGKAT PENGUNGKAPAN INFORMASI WEBSITE TERHADAP FREKUENSI PERDAGANGAN SAHAM PADA PERUSAHAAN PERTAMBANGAN YANG TERDAFTAR DI BEI. Jurnal Ilmiah Manajemen dan Bisnis (JIMBI), 1(2)

Soewadji, Jusuf. (2012). Pengantar Metodologi Peneletian, Jakarta: Mitra Wacana Media

Suherman, M., Wijoyo, H., \& Indrawan, I. (2020). Industry 4.0 vs Society 5.0.

Syahrial, H., \& Robica, D. (2014). ANALISIS PENGARUH STRES KERJA TERHADAP KINERJA DENGAN KEPUASAN KERJA SEBAGAI VARIABEL INTERVINIG PADA PT.PERUSAHAAN GAS NEGARA (PERSERO) MEDAN. JKBM (JURNAL KONSEP BISNIS DAN MANAJEMEN), 1(1), 43-49. doi:https://doi.org/10.31289/jkbm.v1i1.1400

Wijoyo, H. (2005). Peranan Hukum Pajak Dalam Pembangunan Ekonomi. Jurnal Hukum Respublica, 4(2). Wijoyo, H. (2021). Hukum Bisnis. Insan Cendekia Mandiri.

Wijoyo, H., Akbar, M. F., Safii, A. R., Prasada, D., Yusuf, A., Sudarsono, A., \& Widiyant, W. (2021). The Effect of Tax Stimulus During the Covid-19 Pandemic in Improving the Performance of Taxpayers. Available at SSRN 3873695.

Wijoyo, H., Devi, W. S. G. R., Ariyanto, A., \& Sunarsi, D. (2021). The Role of Regular Tax Functions in the Pandemic Period Covid-19 at Pekanbaru. TIN: Terapan Informatika Nusantara, 1(10), 509-512. 